\title{
The utilization of acetic, propionic and butyric acids by growing heifers
}

\author{
By J. A. F. ROOK, C. C. BALCH, R. C. CAMPLING \\ AND L. J. FISHER* \\ National Institute for Research in Dairying, Shinfield, Reading
}

(Received 25 February 1963)

Differing efficiencies of utilization of acetic, propionic and butyric acids in both fasting and fattening sheep have been demonstrated by Blaxter and his colleagues (Armstrong \& Blaxter, 1957 a, $b$; Armstrong, Blaxter \& Graham, 1957). In fasting sheep, when the acids were given singly as the sole source of energy, the heat increment with acetic acid ( $4 \mathrm{r} \%$ of the energy of the metabolized acid) was much higher than that with propionic and n-butyric acids ( 13 and $\mathrm{r} 6 \%$, respectively). With a mixture $(3: 2)$ of propionic and n-butyric acids the heat increment was reduced to $9 \%$, and the addition of acetic acid to this mixture up to a molar proportion of $90 \%$ gave only a small increase in heat increment, up to $15 \%$. In fattening sheep, the efficiency of utilization of acetic acid (heat increment $67 \cdot \mathrm{r} \%$ ) was much less than that of propionic and n-butyric acids $(43 \cdot 7$ and $38 \cdot x \%$, respectively).

In young growing animals, protein deposition may be of equal or greater importance than fat deposition and, because of the high water content of muscle, it may contribute more than fat to any gain in body-weight, but there is no information on the relative efficiencies of utilization of the fatty acids for protein deposition.

This paper describes two experiments in which the effects of intraruminal infusions of acetic, propionic and butyric acids on nitrogen retention and on the gain in bodyweight have been determined. Information was also obtained on the effects of the infusions on the digestibility of the dry matter of the diet and the intake of hay when it was offered ad lib., on the total concentration and relative proportions of the volatile fatty acids in the rumen and on the concentrations of total volatile fatty acids, glucose and ketone bodies in the blood plasma. A preliminary report of the results of the first experiment has been published (Rook, Balch \& Campling, 1960).

\section{EXPERIMENTAL}

Animals and their management. Four Friesian heifers with large permanent rumen fistulas were used in both experiments: their mean age was 22 months at the beginning of the first experiment and 26 months at the beginning of the second. They were housed in a metabolism house (Balch, Johnson \& Machin, 1962).

Experimental design. The order of the treatments, details of which are given in Table I, followed a Latin square design balanced with respect to residual effects in

* Present address: Cornell University, Ithaca, NY, USA. 
both experiments. The allocation of animals to standings and to treatment sequences was random in both experiments.

Foods. Over the first 25 days of the 35 days in each treatment period in Expt $\mathrm{I}$ and throughout Expt 2 the daily basal diet consisted of $5.4 \mathrm{~kg}$ hay (ryegrass-clover hay in Expt $\mathrm{I}$; ryegrass hay in Expt 2), I.I kg dairy concentrate cubes (barley I7, maize 20, wheat bran 20 , decorticated groundnut meal I $_{5}$, copra cake Io, palm-kernel cake 5 , molasses Io, dicalcium phosphate I, calcium carbonate I, and salt $1 \%$, with $5 \times 10^{6}$ i.u. vitamin $A$ and $I \times 10^{6}$ i.u. vitamin $D$ added per ton) and $227 \mathrm{~g}$ decorticated groundnut cake. Over days $26-35$ in Expt $\mathrm{I}$, the quantities of dairy concentrate cubes and of decorticated groundnut cake offered were as above, but the amount of hay offered was $\frac{1}{2}-\mathrm{I} \mathrm{kg}$ in excess of the daily consumption. The daily ration was given in two equal feeds at approximately $12 \mathrm{~h}$ intervals. Water was available at all times.

Treatments. Water and the diluted acids (see Table I) were given as continuous intraruminal infusions (see Rook $\&$ Balch, 196I) throughout each experiment. From the first introduction of an acid the daily amount was increased gradually from about one-quarter of the amount shown in Table $\mathrm{I}$ on the Ist day to the full amount on the $4^{\text {th }}$ day.

Table 1. Details of experimental design in two experiments with a group of four growing Friesian heifers

\begin{tabular}{|c|c|c|c|c|c|}
\hline \multirow[b]{2}{*}{$\begin{array}{c}\text { Expt } \\
\text { no. }\end{array}$} & \multirow[b]{2}{*}{$\begin{array}{l}\text { Details of } \\
\text { Latin square }\end{array}$} & \multirow[b]{2}{*}{$\begin{array}{l}\text { Duration } \\
\text { of each } \\
\text { treatment } \\
\text { (days) }\end{array}$} & \multicolumn{3}{|c|}{ Treatment } \\
\hline & & & & $\begin{array}{l}\text { Infusion given daily into } \\
\text { reticulo-rumen }\end{array}$ & $\begin{array}{l}\text { Calories } \\
\text { supplied by } \\
\text { infusion } \\
\text { (kcal/day) }\end{array}$ \\
\hline I & Balanced* $4 \times 4$ & 35 & $\begin{array}{l}(a) \\
(b) \\
(c) \\
(d)\end{array}$ & $\begin{array}{l}\text { ro gal water } \\
954 \mathrm{ml} \text { acetic acid + Io gal water } \\
706 \mathrm{ml} \text { propionic acid + ro gal water } \\
610 \mathrm{ml} \text { butyric acid + ro gal water }\end{array}$ & $\begin{array}{l}- \\
3500 \\
3500 \\
3500\end{array}$ \\
\hline 2 & Balanced ${ }^{*}{ }_{4} \times 4$ & 35 & $\begin{array}{l}(a) \\
(b) \\
(c) \\
(d)\end{array}$ & $\begin{array}{l}\text { I } 5 \text { gal water } \\
\text { I } 500 \mathrm{ml} \text { acetic acid }+ \text { I } 5 \text { gal water } \\
\text { I I } 10 \mathrm{ml} \text { propionic acid }+ \text { I } 5 \text { gal water } \\
954 \mathrm{ml} \text { butyric acid + I } 5 \text { gal water }\end{array}$ & $\begin{array}{l}- \\
5500 \\
5500 \\
5500\end{array}$ \\
\hline
\end{tabular}

Experimental details. In each period of Expt I there was an introductory period of I I days. On day I I, animals were harnessed for the separate collection of faeces and urine (Balch, Bartlett $\&$ Johnson, I95I) and quantitative collections were made over days I $2-23$ inclusive. On day 25 , samples of rumen liquor were taken at hourly intervals and samples of jugular-vein blood every $3 \mathrm{~h}$. Over days 26-35, measurements of the voluntary intake of hay, when it was offered ad lib., were made. Animals were weighed after the temporary removal of the contents of the reticulo-rumen at $12.00 \mathrm{~h}$ on days 4 and 25 in each period.

In Expt 2, the introductory feeding period extended from day I to day 24 in each period and the quantitative collection of faeces was made over days $25-36$ inclusive. Measurements of body-weight after the temporary removal of the contents of the reticulo-rumen were made at $12.00 \mathrm{~h}$ on days $\mathrm{I}$ and 2 of each period and on the 
2 days succeeding the final period, during which the animals were maintained on their previous experimental diet.

Sampling and methods of analysis. Large representative samples of foods, faeces, urine and 'overflow' (spillage of faeces and urine) were taken. The urine and overflow were collected in acid and a subsample of faeces was stored under acid, for nitrogen determination. A subsample of the faeces and the samples of the foods were dried at $100^{\circ}$ and milled before analysis.

$\mathrm{N}$ was determined by the Kjeldahl method. Samples of rumen liquor were filtered through muslin gauze and then centrifuged for $40 \mathrm{~min}$ at $2500 \mathrm{~g}$. The centrifugate was analysed for total volatile fatty acids by the method of Annison (1954) and every fourth sample for the individual fatty acids by gas chromatography by the method of James \& Martin (1952). Samples of blood plasma were analysed for total volatile fatty acids (Scarisbrick, 1952), glucose (Somogyi, 1952), acetone plus acetoacetic acid, and $\beta$-hydroxybutyric acid (Reid, 1960).

\section{RESULTS}

Nitrogen retention. The mean retention of $\mathrm{N}$ during the control periods was positive in both experiments: retention was slightly higher in Expt 2 (18.0 g/day) than in Expt I (14.6 g/day) (Table 2), probably reflecting the higher digestibility of the dry matter of the diet in Expt 2. In each experiment, all the supplements gave an increase in $\mathrm{N}$ retention but the differences were not significant $(P>0.05)$. The increase in $\mathrm{N}$ retention was, however, greatest with the acetic acid supplement $(7.4 \mathrm{~g} /$ day) and least with the propionic acid supplement ( $3.6 \mathrm{~g} /$ day) in Expt $\mathrm{I}$, but all the supplements gave similar responses, varying only from $3 \cdot 1$ to $4^{\cdot 1} \mathrm{~g}$ /day, in Expt 2.

Table 2. Mean values with their standard errors for retention of $N$, gain in empty-body weight, digestibility of the dry matter of the food and intake of hay offered ad lib. in four growing heifers given a daily intraruminal infusion of water or of acetic, propionic or butyric acid

\begin{tabular}{|c|c|c|c|c|c|}
\hline $\begin{array}{c}\text { Expt } \\
\text { no. }\end{array}$ & Infusion* & $\begin{array}{l}N \text { retention } \\
\text { (g/day) }\end{array}$ & $\begin{array}{c}\text { Change in } \\
\text { empty-body } \\
\text { weight } \\
\text { (kg/day) }\end{array}$ & $\begin{array}{c}\text { Dry-matter } \\
\text { digestibility } \\
(\%)\end{array}$ & $\begin{array}{l}\text { Ad lib. } \\
\text { intake } \\
\text { of hay } 1 \\
\text { (kg/day) }\end{array}$ \\
\hline \multirow[t]{2}{*}{ I } & $\begin{array}{l}\text { Water } \\
\text { Acetic acid } \\
\text { Propionic acid } \\
\text { Butyric acid }\end{array}$ & $\begin{array}{l}14 \cdot 6 \\
22 \cdot 0 \\
18 \cdot 2 \\
19 \cdot 8\end{array}$ & $\begin{array}{l}-0.11 \\
+0.27 \\
+0.17 \\
+0.34\end{array}$ & $\begin{array}{l}56 \cdot 2 \\
56 \cdot 2 \\
57 \cdot 2 \\
56 \cdot 9\end{array}$ & $\begin{array}{l}7 \cdot 5 \\
6 \cdot 5 \\
7 \cdot 0 \\
7 \cdot 1\end{array}$ \\
\hline & $\begin{array}{l}\text { S.e. of differences between } \\
\text { two means }\end{array}$ & $\pm 3 \cdot 24$ & \pm 0.175 & \pm 0.97 & \pm 0.25 \\
\hline \multirow[t]{2}{*}{2} & $\begin{array}{l}\text { Water } \\
\text { Acetic acid } \\
\text { Propionic acid } \\
\text { Butyric acid }\end{array}$ & $\begin{array}{l}18 \cdot 0 \\
21 \cdot 1 \\
21 \cdot 9 \\
22 \cdot 10\end{array}$ & $\begin{array}{l}+0.10 \\
+0.61 \\
+0.64 \\
+0.77\end{array}$ & $\begin{array}{l}69 \cdot 8 \\
66 \cdot 5 \\
68 \cdot 6 \\
70 \cdot 4\end{array}$ & $\begin{array}{c}- \\
- \\
-\end{array}$ \\
\hline & $\begin{array}{l}\text { SE of differences between } \\
\text { two means }\end{array}$ & $\pm 3.5^{8}$ & \pm 0.088 & \pm 0.63 & - \\
\hline \multicolumn{6}{|c|}{$\begin{array}{l}\text { For details of infusion see Table } 1 \text {. } \\
\dagger \text { For method of calculating empty-body weight see p. } 402 \text {. } \\
\text { I retention, change in empty-body weight and dry-matter digestibility were determined wit } \\
\text { itakes of hay equal for all treatments. }\end{array}$} \\
\hline \multicolumn{2}{|l|}{26} & \multicolumn{4}{|c|}{ Nutr. 17,3} \\
\hline
\end{tabular}


Empty-body weight gain. Empty-body weight was determined by subtracting the weight of total gut contents from the live weight. Total gut contents were calculated on the assumption that the amount in the reticulo-rumen made up $73 \%$ of that in the total gut (Mäkelä, I956). On average, there was a small loss $(-0 \cdot 1 \mathrm{I} \mathrm{kg} /$ day) in emptybody weight in animals during control feeding in Expt I and a small gain $(+0.10 \mathrm{~kg} /$ day) in Expt 2 (Table 2). All the supplements gave an increase in empty-body weight gain, with a mean value of $0.37 \mathrm{~kg} /$ day in Expt I and $0.56 \mathrm{~kg} /$ day in Expt 2: the effect was not significant in Expt I $(P>0.05)$ but highly significant $(P<0.01)$ in Expt 2. Differences in the responses to the individual acids were not significant $(P>0.05)$ but the highest gains were obtained with the butyric acid supplement in both experiments.

Table 3. Mean values of acetic, propionic and butyric acid for fat deposition and calorie retention in four growing heifers, as calculated from nitrogen retention and empty-body weight gain

\begin{tabular}{|c|c|c|c|c|c|c|}
\hline $\begin{array}{c}\text { Expt } \\
\text { no. }\end{array}$ & Infusion & $\begin{array}{c}\text { Empty- } \\
\text { body } \\
\text { weight } \\
\text { gain } \\
\text { (g/day) }\end{array}$ & $\begin{array}{c}\mathrm{N} \\
\text { retention } \\
(\mathrm{g} / \text { day })\end{array}$ & $\begin{array}{l}\text { Gain of } \\
\text { fat-free* } \\
\text { material } \\
\text { (g/day) }\end{array}$ & $\begin{array}{c}\text { Fat } \\
\text { deposition } \\
\text { (g/day) }\end{array}$ & $\begin{array}{c}\text { Calculated } \dagger \\
\text { calorific value } \\
\text { of gain in } \\
\text { empty-body } \\
\text { weight } \\
\text { (kcal/day) }\end{array}$ \\
\hline I & $\begin{array}{l}\text { Acetic acid } \\
\text { Propionic acid } \\
\text { Butyric acid }\end{array}$ & $\begin{array}{l}377 \\
281 \\
450\end{array}$ & $\begin{array}{l}7 \cdot 4 \\
3 \cdot 6 \\
5 \cdot 2\end{array}$ & $\begin{array}{l}211 \\
103 \\
148\end{array}$ & $\begin{array}{l}166 \\
178 \\
302\end{array}$ & $\begin{array}{l}1802 \\
1787 \\
3003\end{array}$ \\
\hline 2 & $\begin{array}{l}\text { Acetic acid } \\
\text { Propionic acid } \\
\text { Butyric acid }\end{array}$ & $\begin{array}{l}477 \\
554 \\
663\end{array}$ & $\begin{array}{l}3 \cdot 1 \\
3 \cdot 9 \\
4 \cdot 1\end{array}$ & $\begin{array}{r}88 \\
\text { III } \\
117\end{array}$ & $\begin{array}{l}389 \\
443 \\
546\end{array}$ & $\begin{array}{l}3743 \\
4280 \\
5246\end{array}$ \\
\hline
\end{tabular}

Using the factors given by Blaxter ( 1962 ) for the calculation from $\mathrm{N}$ retention of fat-free material deposited in the body, estimates have been made of fat deposition and the results are given in Table 3. From these figures the calorific value of the gain in empty-body weight has been estimated, with the factors of Blaxter \& Rook (1953), and the efficiency of utilization of the energy of the infused acids calculated; no allowance was made for changes in the digestibility of the diet. These estimates of the efficiency of utilization of the energy of the infused acids were much higher than those obtained in the calorimetric experiments of Armstrong \& Blaxter (1957b), indicating the considerable errors that are involved in the many assumptions made: but in comparative terms the results of the two experiments described here are consistent in indicating a much higher efficiency of utilization of the energy of butyric acid than of propionic or acetic acid.

Effects of the infusion of the acids on conditions within the reticulo-rumen. The mean values for $\mathrm{pH}$, the concentration of the total volatile fatty acids and the molar proportions of the individual acids in the rumen liquor in Expt $I$ are given in Table 4. The intraruminal infusion of acetic acid caused a significant $(P<0.05)$ decrease, of 0.32 units, in rumen $\mathrm{pH}$ but the infusions of propionic and butyric acid were without 
effect. The concentration of total volatile fatty acids in rumen liquor was increased with all three of the acids $(P<0.01)$, the increase noted being roughly proportional to g-equiv. of acid added: at the same time, there was an increase in the molar proportion of the acid being infused with a proportional decrease in the other acids. There was no evidence that the proportions among the acids other than the infused acid were changed, with the possible exception of a slight increase in valeric acid when propionic or butyric acid was being infused.

Table 4. Expt $\mathrm{I}$. Mean values with their standard errors for $\mathrm{pH}$, concentration of total volatile fatty acids and molar proportion of the individual acids in the rumen liquor of four heifers receiving intraruminal infusions of water or of a solution of acetic, propionic or butyric acid

\begin{tabular}{|c|c|c|c|c|c|c|}
\hline \multirow[b]{2}{*}{ Infusion } & \multirow[b]{2}{*}{$\mathrm{pH}$} & \multirow{2}{*}{$\begin{array}{c}\text { Total } \\
\text { volatile fatty } \\
\text { acids } \\
\text { (m-equiv. } / 100 \mathrm{~g} \text { ) }\end{array}$} & \multicolumn{4}{|c|}{$\begin{array}{l}\text { Molar proportions of individual } \\
\text { fatty acids in rumen liquor }\end{array}$} \\
\hline & & & $\begin{array}{l}\text { Acetic } \\
\text { acid }\end{array}$ & $\begin{array}{l}\text { Propionic } \\
\text { acid }\end{array}$ & $\begin{array}{l}\text { Butyric } \\
\text { acid }\end{array}$ & $\begin{array}{l}\text { Valeric } \\
\text { acid }\end{array}$ \\
\hline $\begin{array}{l}\text { Water } \\
\text { Acetic acid } \\
\text { Propionic acid } \\
\text { Butyric acid }\end{array}$ & $\begin{array}{l}6 \cdot 35 \\
6 \cdot 03 \\
6 \cdot 37 \\
6 \cdot 31\end{array}$ & $\begin{array}{r}8.66 \\
11 \cdot 18 \\
10.00 \\
9.42\end{array}$ & $\begin{array}{l}69 \cdot 1 \\
78 \cdot 0 \\
52 \cdot 6 \\
56 \cdot 8\end{array}$ & $\begin{array}{l}18 \cdot 2 \\
13 \cdot 1 \\
36 \cdot 3 \\
16 \cdot 2\end{array}$ & $\begin{array}{r}9 \cdot 8 \\
6 \cdot 8 \\
8 \cdot 3 \\
24 \cdot 1\end{array}$ & $\begin{array}{l}2 \cdot 8 \\
2 \cdot 2 \\
2 \cdot 9 \\
3 \cdot 0\end{array}$ \\
\hline $\begin{array}{l}\text { SE of differences between two } \\
\text { means }\end{array}$ & \pm 0.077 & $\pm 0.3^{88}$ & $\pm I \cdot 53$ & $\pm 1 \cdot 28$ & \pm 0.95 & \pm 0.22 \\
\hline
\end{tabular}

Table 5. Expt I. Mean values with their standard errors for concentrations of sugar, total volatile fatty acids, acetone plus acetoacetic acid, and $\beta$-hydroxybutyric acid in the plasma of peripheral blood of four growing heifers receiving intraruminal infusions of water or of a solution of acetic, propionic or butyric acid

\begin{tabular}{|c|c|c|c|c|}
\hline Infusion & $\begin{array}{c}\text { Sugar } \\
(\mathrm{mg} / 1 \infty \mathrm{ml})\end{array}$ & $\begin{array}{l}\text { Total volatile } \\
\text { fatty acids } \\
\text { (m-equiv./l.) }\end{array}$ & $\begin{array}{l}\text { Acetone + aceto- } \\
\text { acetic acid } \\
(\mathrm{mg} / 100 \mathrm{ml})\end{array}$ & $\begin{array}{c}\beta \text {-hydroxybutyric } \\
\text { acid } \\
(\mathrm{mg} / 100 \mathrm{ml})\end{array}$ \\
\hline $\begin{array}{l}\text { Water } \\
\text { Acetic acid } \\
\text { Propionic acid } \\
\text { Butyric acid }\end{array}$ & $\begin{array}{l}71 \cdot 8 \\
74 \cdot 8 \\
73 \cdot 3 \\
71 \cdot 3\end{array}$ & $\begin{array}{l}0.36 \\
0.91 \\
0.34 \\
0.36\end{array}$ & $\begin{array}{l}0.18 \\
0.18 \\
0.21 \\
0.31\end{array}$ & $\begin{array}{l}2 \cdot 09 \\
2 \cdot 44 \\
1 \cdot 52 \\
6 \cdot 73\end{array}$ \\
\hline SE of differences between two & $\pm \mathrm{I} \cdot 87$ & \pm 0.075 & \pm 0.023 & $\pm 0.49 I$ \\
\hline
\end{tabular}

Effects of the infusion of the acids on the digestibility of the dry matter of the diet and on the voluntary intake of hay (Expt $\mathrm{r}$ ). The digestibility of the dry matter of the diet was unaffected in Expt I, but at the higher level of acid infusion in Expt 2 the infusion of acetic acid was associated with a significant $(P<0.05)$ reduction in dry-matter digestibility ('Table 2$)$. The ad lib. intake of hay was significantly $(P<0.05)$ depressed only by the infusion of acetic acid in Expt I. Measurements of the ad lib. intake of hay were not made in Expt 2. Balch \& Campling (1962) have discussed these results in relation to the chemostatic theory of the regulation of food intake by ruminants.

Effects of infusion of the acids on the composition of the blood plasma (Expt $\mathrm{I})$. No significant effect on the concentration of glucose in the blood plasma was observed (Table 5). The infusion of acetic acid caused a highly significant $(P<0.01)$ increase 
in the total volatile fatty acid concentration of the plasma but the other acids were without effect. The infusion of butyric acid produced a very highly significant increase $(P<0.00 \mathrm{I})$ in the $\beta$-hydroxybutyric acid content of blood plasma and a proportionately smaller, but still highly significant $(P<0.01)$, increase in acetone plus acetoacetic acid content. A small increase in $\beta$-hydroxybutyric acid content with the infusion of acetic acid and a small decrease with the infusion of propionic acid were also obtained, but these effects were not significant $(P>0.05)$. These observations are consistent with present knowledge of the metabolism of the acids, and do not indicate any abnormality resulting from infusion of the acids.

\section{DISCUSSION}

The technique of continuously infusing dilute aqueous solutions of the volatile fatty acids into the rumen to study their metabolism is open to the criticism that abnormal physiological conditions might be produced within the rumen, and the digestion of the basal diet and the absorption of the end-products of digestion modified. The reductions in the voluntary intake of hay and in the digestibility of the dry matter of the diet during the infusion of acetic acid are indicative of such effects. These effects were, however, slight and there was no suggestion that the production of acids within the rumen was altered. No abnormalities due to the infusion of propionic or butyric acids were noted. Because of the restriction of the amounts of acids infused to minimize possible harmful effects, however, the responses to the infused acids in $\mathrm{N}$ retention in both experiments and the gain in empty-body weight in the first experiment did not achieve statistical significance.

The two experiments were consistent in indicating a higher efficiency of utilization of the energy of butyric acid than of propionic or acetic acid, as judged from the $\mathrm{N}$ retention and estimated fat storage: in both experiments energy was stored mainly as fat. The more precise calorimetric experiments of Armstrong \& Blaxter (I957b), however, have indicated that the efficiency of utilization of both butyric and propionic acids for lipogenesis is considerably higher than that of acetic acid, and clearly little reliance can be placed on the information presented here concerning the relative efficiency of the utilization of the energy of the acids. In terms of $\mathrm{N}$ retention, however, there was a trend towards a higher response to the infusion of acetic than of butyric or propionic acid in Expt 1 , and differences in the ability of the fatty acids to promote $\mathrm{N}$ retention may exist. It is evident that experiments should be made under more critical conditions with young animals having a greater propensity for growth than the animals used in the experiments described here.

As an outcome of the observations of Armstrong \& Blaxter (1957b) on the relative inefficiency of the utilization of acetic acid in lipogenesis, interest has centred on the possibility of altering the efficiency of food conversion in cattle by modifying the endproducts of rumen fermentation. For example, altering the physical condition of a diet, by fine-grinding of the roughage and cooking of the concentrates, and the addition to the diet of cod-liver oil or specific unsaturated fatty acids have been shown (see Shaw, 1961) to favour the production in the rumen of propionic acid at the expense 
of acetic acid, and Shaw, Ensor, Tellechea \& Lee (1960) observed an increased rate of weight gain and efficiency of food conversion by steers in response to the grinding of the hay and cooking of the concentrates of a diet, which they attributed largely to a changed pattern of rumen fermentation. Our limited observations do not indicate any marked difference in the efficiency with which acetic and propionic acids promote live-weight gains, but it is not possible to relate our observations, for which the technique of infusing acids into the rumen was used, with those obtained with changes in the physical condition of natural foods, since information is not available on the relative caloric efficiency of the production in the rumen of individual fatty acids from food constituents. In explaining the effect of the physical condition of the diet on the growth performance of animals, it should also be recognized that the digestibility of dietary constituents is altered and probably also the proportion of energy absorbed as fatty acids. Such factors could offset or enhance any effect due to a change in the relative proportions of the fatty acids produced in the rumen. Shaw et al. (1960) obtained a growth response in steers given a diet of lucerne hay, maize and linseed-oil meal, in the ratio of $1: 1: 0.04$, whereas Blaxter \& Graham (1956) observed no difference with sheep in the net energy value of dried grass when it was given finely ground or in the long form.

\section{SUMMARY}

1. 'Two experiments were made with four non-lactating Friesian heifers given a basal diet of hay, dairy cubes and decorticated groundnut meal. Each animal received, over successive periods of 35 days, a continuous intraruminal infusion of water or of an aqueous solution of acetic, propionic or butyric acid, according to a Latin square design. The acids supplied $3500 \mathrm{kcal} /$ day in Expt I and $5500 \mathrm{kcal} /$ day in Expt 2. Measurements were made of the effects of the infusions on nitrogen retention, change in empty-body weight, voluntary food intake, digestibility, volatile fatty acids in rumen liquor, and certain blood constituents.

2. The infusion of acetic acid depressed the $\mathrm{pH}$ of the rumen liquor slightly, decreased the ad lib. intake of hay and, in Expt 2 but not in Expt I, decreased the digestibility of the dry matter of the diet. Similar effects were not observed with the infusion of propionic or butyric acid. All the acids gave an increase in the total volatile fatty-acid concentration of the rumen liquor, with an increase in the molar proportion of the acid being infused and decreases in the proportions of the other acids. The acids had no effect on the concentration in blood plasma of glucose, but the infusion of acetic acid increased the concentration of volatile fatty acids and the infusion of butyric acid increased the concentration of $\beta$-hydroxybutyric acid and of acetone plus acetoacetic acid.

3. All the acids gave an increase in $\mathrm{N}$ retention in both experiments; the mean increase in Expt I was 5.4 g/day and in Expt 2 it was $3.7 \mathrm{~g} /$ day. The effects were not significant but the greatest increase occurred with the infusion of acetic acid in Expt 1 . Increases in body-weight occurred in response to the infusions of all the acids, and in Expt 2 the effect was significant $(P<0.05)$ though the difference in response between 
supplements was in no instance significant $(P>0.05)$; in both experiments the rate of gain was highest with the infusion of butyric acid.

4. The results are discussed in relation to the effect of type of rumen fermentation on the efficiency of utilization of food for growth.

We are grateful to Mr V. W. Johnson for the care of the experimental animals and to Mrs P. Christie and Mr D. Millard for skilled technical assistance.

\section{REFERENCES}

Annison, E. F. (1954). Biochem. $\mathcal{~} .57,400$.

Armstrong, D. G. \& Blaxter, K. L. (1957a). Brit. F. Nutr. 11, 247.

Armstrong, D. G. \& Blaxter, K. L. (1957b). Brit. F. Nutr. Ir, 4I3.

Armstrong, D. G., Blaxter, K. L. \& Graham, N. McC. (1957). Brit. F. Nutr. 11, 392.

Balch, C. C., Bartlett, S. \& Johnson, V. W. (195 I). F. agric. Sci. 41, 98.

Balch, C. C. \& Campling, R. C. (1962). Nutr. Abstr. Rev. 32, 669.

Balch, C. C., Johnson, V. W. \& Machin, C. (1962). F. agric. Sci. 59, 355.

Blaxter, K. L. (1962). The Energy Metabolism of Ruminants. London: Hutchinson.

Blaxter, K. L. \& Graham, N. McC. (1956). F. agric. Sci. 47, 207.

Blaxter, K. L. \& Rook, J. A. F. (1953). Brit. F. Nutr. 7, 83.

James, A. T. \& Martin, A. J. P. (1952). Biochem. F. 50, 679.

Mäkelä, A. (1956). Suom. Maataloust. Seur. Fulk. no. 85.

Reid, R. I. (1960). Analyst, 85, 265.

Rook, J. A. F. \& Balch, C. C. (1961). Brit. F. Nutr. 15, 36r.

Rook, J. A. F., Balch, C. C. \& Campling, R. C. (1960). Proc. Nutr. Soc. 19, i.

Scarisbrick, R. (1952). Biochem. $\mathcal{F . ~ 5 0 , ~ x x x i v . ~}$

Shaw, J. C. (1961). Int. Congr. Anim. Husb. vin. Hamburg. Vol. 1, p. 29.

Shaw, J. C., Ensor, W. L., Tellechea, H. F. \& Lee, S. O. (1960). F. Nutr. 7r, 203.

Somogyi, M. (1952). F. biol. Chem. 195, 19. 